\title{
New data on plume moths (Lepidoptera: Pterophoridae) of Panama
}

\section{Новые сведения о пальцекрылках (Lepidoptera: Pterophoridae) Панамы}

\author{
V.N. Kovtunovich ${ }^{1}$, P.Ya. Ustjuzhanin ${ }^{2}$ \\ В.Н Ковтунович ${ }^{1}$, П.Я Устюжканин
}

\footnotetext{
${ }^{1}$ Moscow Society of Nature Explorers, Bolshaya Nikitskaya Str. 2, Moscow 125009, Russia, E-mail: vasko-69@mail.ru

${ }^{1}$ Московское общество испытателей природы, ул. Большая Никитская 2, Москва, 125009, Россия.

2 Altai State University, Lenina Prospekt 61, Barnaul, RU-656049, Russia, E-mail: petrust@mail.ru.

2 Алтайский государственный университет, пр. Ленина 61, Барнаул 656049, Россия.
}

KEY WORDS: Pterophoridae, Central America, Panama, new species, new data.

КЛЮЧЕВЫЕ СЛОВА: Pterophoridae, Центральная Америка, Панама, новый вид, новые данные.

ABSTRACT. Examining the Pterophoridae specimens from Panama given to us for consideration, we have found one species new to science: Hellinsia antonkozlovi Kovtunovich et Ustjuzhanin, sp.n., and also Hellinsia hebrus (Meyrick, 1932) new for the fauna of the country.

РЕЗЮМЕ. По материалам, собранным в Панаме, и переданным нам на обработку, выявлен один новый вид пальцекрылок - Hellinsia antonkozlovi Kovtunovich et Ustjuzhanin, sp.n., Hellinsia hebrus (Meyrick, 1932) впервые указана для Панамы.

\section{Introduction}

The sub-equatorial climate of Panama with heavily dissected ridges and mountain peaks provide favorable habitat for wild flora and fauna. However, the information on the plume moths of this country is rather scanty. From literature, 14 Pterophoridae species were known for Panama [Walsingham, 1915; Meyrick, 1929; Arenberger, 1990; Gielis, 2003, 2006, 2011]. As a result of replenishment by new material from the expedition by A. Kozlov, Yu. Kovaleva, R. Gortovannyi (Moscow), two more species were added, one of which turned out to be new to science. The holotype of the new species is deposited in the Zoological Institute of Russian Academy of Science, St. Petersburg (ZISP).

\section{List of species}

Ochyrotica fasciata Walsingham, 1891

DISTRIBUTION. Cuba, Dominica, Puerto Rico, Jamaica, Guatemala, Grenada, Costa Rica, Panama, Cocos Island, Brazil [Gielis, 2003].
Ochyrotica gielisi Arenberger, 1990

DISTRIBUTION. Panama [Arenberger, 1990].

Ochyrotica placozona Meyrick, 1921 003].

Leptodeuterocopus panamaensis Gielis, 2006

DISTRIBUTION. Panama [Gielis, 2006].

Sochchora dotina Walsingham, 1915

DISTRIBUTION. Panama, Venezuela, French Guyana, Brazil [Gielis, 2003, 2014].

Sphenarches anisodactylus (Walker, 1864)

DISTRIBUTION. Pantropical species.

Marasmarcha brevirostris (Walsingham, 1915) 2003].

DISTRIBUTION. Mexico, Guatemala, Panama [Gielis,

Megalorhipida leucodactylus (Fabricius, 1794)

DISTRIBUTION. Pantropical species.

Hellinsia hebrus (Meyrick, 1932)

MATERIAL EXAMINED. $1 \sigma^{\top}$, PANAMA. Ngabe Bugle Co-

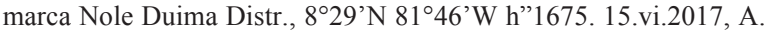
Kozlov, Yu. Kovaleva, R. Gortovannyi.

DISTRIBUTION. Costa Rica [Gielis, 2003], Panama.

NOTE. New for Panama.

Hellinsia mollis (Walsingham, 1915)

DISTRIBUTION. Guatemala, Costa Rica, Mexico, Panama [Gielis, 2003].

Hellinsia phloeochroa (Walsingham, 1915)

DISTRIBUTION. Mexico, Guatemala, Panama, Venezuela [Gielis, 2003, 2014].

How to cite this article: Kovtunovich V.N., Ustjuzhanin P.Ya. 2018. New data on plume moths (Lepidoptera: Pterophoridae) of Panama // Russian Entomol. J. Vol.27. No.2. P.199-201. doi: 10.15298/rusentj.27.2.10 


\section{Hellinsia antonkozlovi}

Kovtunovich et Ustjuzhanin, sp.n.

Figs $1-4$.

MATERIAL. Holotype: $0^{7}$, (ZISP, gen.pr. Nr. 1905), West

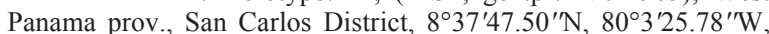
h 870, 13.vi.2017, A. Kozlov, Yu. Kovaleva, R. Gortovannyi.

DESCRIPTION. External characters. Head in pale brown scales, thorax and tegulae white. Labial palpus brown, thin, short, slightly tapered to apex, a little smaller than eye diameter. Antenna yellowish-brown. Wingspan $19.5 \mathrm{~mm}$. Fore wings unicolorous, buffy-yelow. Costal edge brown with whitish outer fringe. Fringe inside cleft pale brown. Hind wings greyish-brown, slightly darker than fore wing, fringe unicolorous, brown-grey. Legs pale yellow, almost white. Spurs on hind legs of unequal length, the outer shorter than the inner.

Male genitalia. Valves asymmetric, narrow. Hapre on left valve thin, arched, located in central part. Sacculus of right valve in shape of large hook located in central part. Anellus arms quite short, of unequal length, the right significantly longer and wider. Saccus arched. Uncus narrow, thin, equal to left harpe in length. Phallus slightly curved, noticeably widened distally, almost twice shorter than valve.

Female unknown.

DIAGNOSIS. In the wings color and the harpe shape in the male genital structure, the new species resembles to Hellinsia cosangae Gielis, 2012, described from Ecuador, but differs from it by the absence of dark costal edge on the fore wing and poorly expressed spot of scales in the cleft base. In the male genitalia it differs from all the known species by the uncinate harpe on the right valve.

ETYMOLOGY. The species is named after Anton Kozlov, entomologist and naturalist, who has collected the new species.

Oidaematophorus trachyphloeus (Meyrick, 1926)

MATERIAL EXAMINED. $2 \sigma^{7} \sigma^{7}, 1$, PANAMA. Chiriqui prov., Bugaba Distr., $8^{\circ} 50^{\prime} \mathrm{N} 82^{\circ} 41^{\prime} \mathrm{W}, \mathrm{h}-1590 \mathrm{~m}, 26 . v i .2017$, A. Kozlov, Yu. Kovaleva, R. Gortovannyi.

DISTRIBUTION. Guatemala, Costa Rica, Panama [Gielis, 2003, 2011].

Oidaematophorus eupatorii (Fernald, 1891)

DISTRIBUTION. Canada, U.S.A., Mexico, Guatemala, Panama [Gielis, 2003].

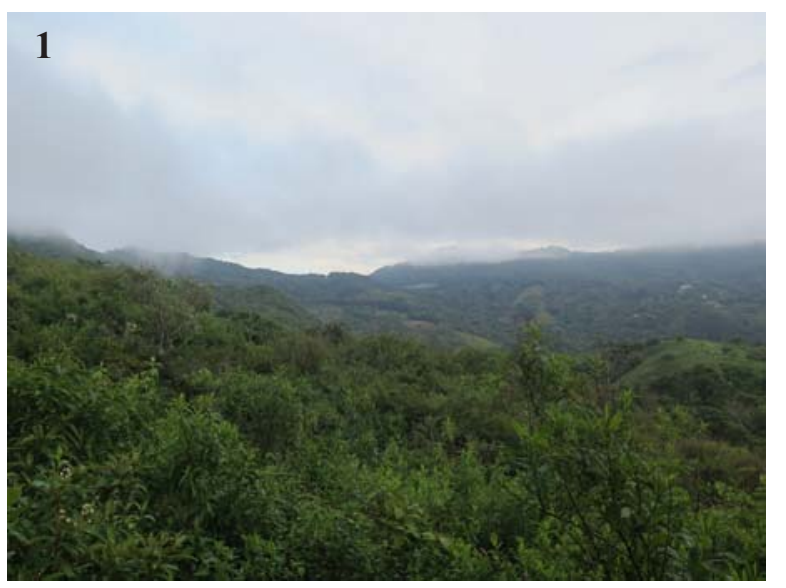

Adaina invida (Meyrick, 1908)

DISTRIBUTION. Costa Rica, Panama, Brazil, Paraguay [Gielis, 2003, 2011, 2012].

\section{Adaina primulacea Meyrick, 1929}

DISTRIBUTION. Costa Rica, Panama [Gielis, 2003].

Thus, the Pterophoridae fauna of Panama currently includes 16 species of nine genera. Due to the poor study of plume moths in this region, the data on their habitat are not complete. There is no doubt that in the future research the species composition of the Pterophoridae fauna of Panama will increase at least twice.

ACKNOWLEDGEMENTS. The authors express their sincere gratitude to Anton O. Kozlov, Julia A. Kovaleva and Roman S. Gortovannyi (all Moscow, Russia) for providing the specimens of Pterophoridae collected in Panama.

\section{References}

Arenberger E. 1990. Die bisher bekannten Ochyrotica-Arten Mittelund Südamerikas // Entomologische Zeitschrift Frankfurt am Main. Bd.100. S.233-243.

Gielis C. 2003. Pterophoroidea \& Alucitoidea // World Catalogue of Insects. Vol.4. Stenstrup: Apollo Books. 198 pp.

Gielis C. 2006. Review of the Neotropical species of the family Pterophoridae, part I: Ochyroticinae, Deuterocopinae, Pterophorinae (Platyptiliini, Exelastini, Oxyptilini) // Zoologische Mededelingen Leiden. Vol.80. P.1-290.

Gielis C. 2011. Review of the Neotropical species of the family Pterophoridae, part II: Pterophorinae (Oidaematophorini, Pterophorini) // Zoologische Mededelingen Leiden. Vol.85. P.589824.

Gielis C. 2012. Review of the Neotropical species of the family Pterophoridae, part III: Additions from Chile, Ecuador and Paraguay // Boletin de la Sociedad Entomologica Aragonesa Vol.51. P.105-124.

Gielis C. 2014. Review of the Neotropical species of the family Pterophoridae, part V: Additions from Peru, Ecuador Colombia, Venezuella and the Guyanas // Boletin de la Sociedad Entomologica Aragonesa. Vol.55. P.67-91.

Meyrick E. 1929. Exotic Microlepidoptera. Vol.3. P.481-512.

Walsingham M. 1915. Biologia Centrali-Americana.Insecta. Lepidoptera-Heterocera. 4. Tineina, Pterophorina, Orneodina, and Pyralidina and Hepialina (part.). P.i-xii, 1-482, 10 plates. Leiden.

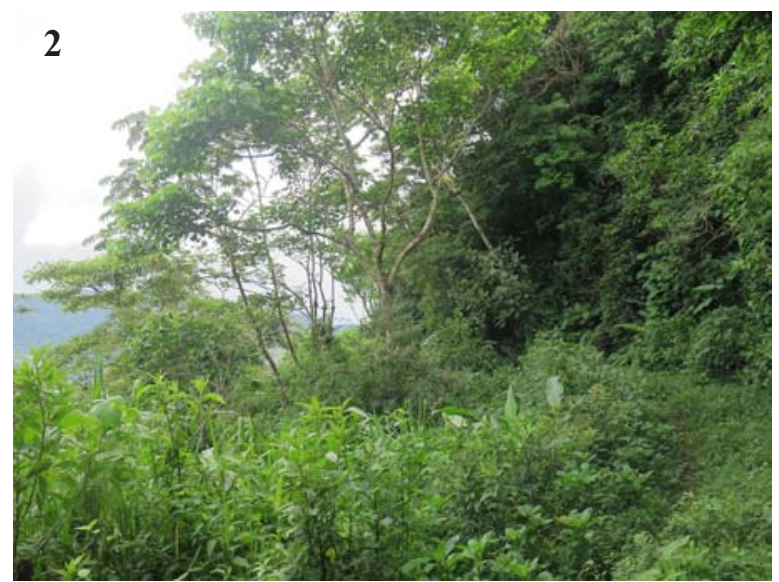

Figs 1-2. Panama, San Carlos District, h-870 m, biotopes (photo by A. Kozlov).

Рис. 1-2. Панама, район Сан Карлос, 870 м, биотопы (фото А. Козлова). 


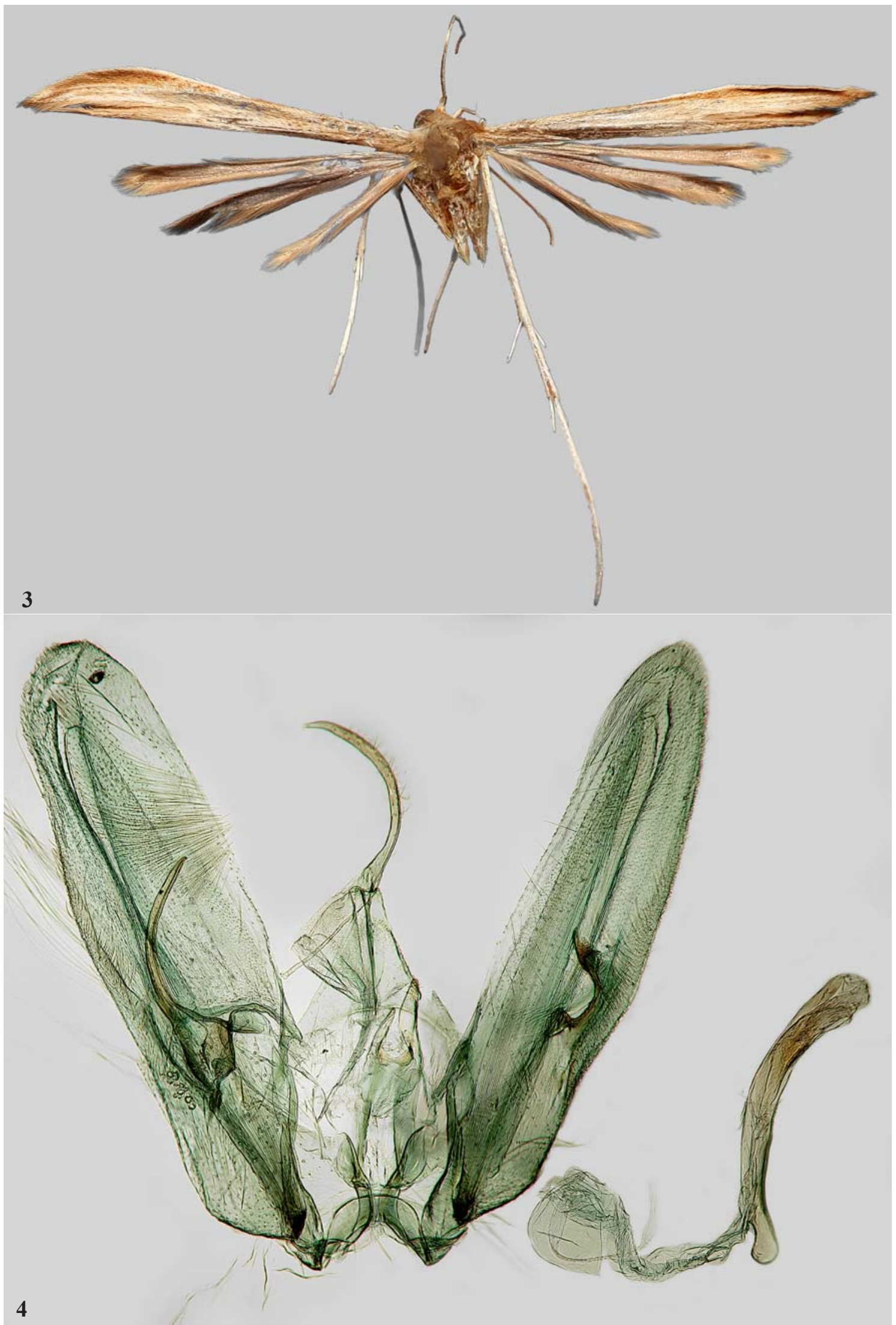

Figs 3-4. Hellinsia antonkozlovi Kovtunovich et Ustjuzhanin, sp.n., male, holotype: 1 - adult; 2 - genitalia (ZISP, gen.pr. Nr.1905). Pис. 3-4. Hellinsia antonkozlovi Kovtunovich et Ustjuzhanin, sp.n., самец, голотип: 1 - имаго; 2 - гениталии (ZISP, gen.pr. Nr. 1905). 